\title{
Fast fashion model product development system: a case study in a brazilian shirt manufacturing
}

\author{
Flávia Nunes Ferreira ${ }^{a}$ Eduardo Romeiro Filho \\ -Departamento de Engenharia de Produç̃õo, Universidade Federal de Minas Gerais - UFMG \\ bLaboratório Integrado de Design e Engenharia do Produto, Departamento de Engenharia de Produção, Escola de Engenharia, Universidade Federal de Minas Gerais - UFMG \\ e-mails: flavianfe@gmail.com; romeiro@dep.ufmg.br; edu.romeiro@gmail.com
}

\begin{abstract}
The clothing industry has gone through different scenarios in the last decades and, along with technological revolutions and the advent of the internet, fashion has become more ephemeral, with the emergence of a new retail business model denominated "fast fashion". This is a set of strategies for rapid product development and production that contemplate the eminent fashion trends, adopted by the growing number of companies in Brazil, where a formalized product development methodologies or models is almost nonexistent. In addition, the application of fast fashion by the Brazilian industry has been little studied and the organization of its Product Development System (PDS) is still not widespread. In view of this situation, this paper aims to evaluate the fast fashion business model in a Brazilian industry, elaborated through a literature review on the model and methods of development of fashion products, in addition to a case study in a medium-sized men's shirt industry.
\end{abstract}

Keywords: product development system, fast fashion, clothing industry.

\section{Introduction}

It can be said that practically all the existing market models are somehow (directly or indirectly) based on consumption, as it is an incentive for decision-making by companies in the market, whether in the textile sector or any other. Thus, fashion and consumption become sides of the same coin. Fast fashion is born to meet the consumer's desires and consumption acceleration with the speed with which trends appear, with adequate products. In this sense, it is possible to affirm that the creation of the fashion product is continuous and the new demands are dictated by consumers.

The quick launch of differentiated products has quickly been seen as a way out of the growing competitive pressure. Therefore, an organized product development processes reducing the time between product planning and its launch, with regard to the sequencing of activities and the integration between departments, are not trivial for the development of successful products. Little is known about the experiences of Brazilian companies that adopt the fast fashion model due to the lack of studies carried out (CIETTA, 2010). However, a relevant data from the national fashion industry states that many of them have product development systems, but with a low level of organization (OLIVEIRA, 2007). The question then arises: how do small and medium-sized companies that adopt the fast fashion model develop their products?
In this context, studies about the organization and structuring of the product development process of the clothing industries are necessary. The present study intends to contribute with information for the concurrence and success of this segment of products with short cycles, which intends to serve demanding consumers both in design and in innovation. The objective is to analyze the PDS - Product Development System (PESSÔA; TRABASSO, 2017) applied in the clothing industries that use the fast fashion model and, based on the Product Development Process (PDP) models found in the literature, to collect data aiming to improve this process that allows an agile, robust and effective PDP.

To carry out the proposal, literature review and a case study on a fast fashion model Brazilian manufacturer was carried out, in an exploratory research, with qualitative approach and of an applied nature, which is of interest in application, use and consequences knowledge practices generated in a circumstantial reality (GIL, 2019), through documentary analysis, interviews, personal testimonies, direct observation and analysis of physical artifacts.

\section{Fast fashion}

According to Cietta (2010), fast fashion is nothing more than a business model adopted by a certain brand / company. It is not a market positioning or a fashion trend, it is a retail 
model with several complex production chains, acting together, and which, for full functioning, must be very well structured. The system has attracted the attention of the clothing market as it is able to reproduce in a unique way the trends and desires of consumers. Given the immaterial values inserted in fashion consumption, the model of rapid production and distribution gains strength in the clothing sector. Able to respond satisfactorily to the demands of accelerated consumption, fast fashion makes its success evident by providing companies with more sales and consequently income, in addition to customer loyalty. Another fundamental aspect of the system in question is the search for an affordable price.

Fast fashion products are disposable and this is what makes the consumer return to the store and look for news more often than they would look for any product [...] (SANTIAGO; MORELLI, 2010, p. 4).

Still according to the authors, customers want to adapt to fashion trends, but are not willing to pay dearly for it.

Fast fashion is a strategy in response to today's hyper consumption. In search of agility and to minimize stock quantities, the creations are characterized by being semi-exclusive production in batches, however smaller and unique. Aesthetics and style of clothing are valued, but in a way aimed at a popular market, where exclusivity is not important "[...] but price is the primary factor to the detriment of aesthetics [...]" (DELGADO, 2008, p. 5). The visual appeal prevails in the collections and quality is no longer a priority, in order to meet the demand for the search for the new. This new strategy can be considered a marketing phenomenon of the current fashion and without distinction of classes, it starts to be consumed by people of all social status, predominating the middle and working classes. Currently, even if a brand does not formally adhere to this model, it is influenced by the concept of fast fashion.

It can be said, then, that the fast fashion model seeks to reduce the uncertainties of demand and, at the same time, increase consumption, through the production of short life cycle products, so that its launch is the closest possible from the time of sale and in accordance with the consumer's wishes at that time. Also according to Cietta (2010, p. 16) the fast fashion model

[...] can, paradoxically, be very effective in defending the local productive heritage, as long as it can exploit the advantage of knowing how to anticipate changes in consumption trends in the local market, more than the big global competitors.

This model may prove to be an effective corporate policy strategy in the development of local networks, so that it can defend the national industry much better than taxes or trade barriers, since the geographical and cultural proximity to the market is a significant differential in this process. In addition, the local market offers important indications on consumer behavior for the fashion industry, such as (for example), the "soap opera fashion" (considered as a Brazilian peculiarity).

\subsection{Textile product development}

Based on the product development process proposed by Slack et al.(2018), Kotler (2011) and Munari's design methodology (1975), Rech (2002) proposes a methodology for the textile industry, in an interdisciplinary and simultaneous approach. Under these views, the author proposes the development of the fashion product in five moments (Table 1): Concept Generation, that involves analysis of previous collections, marketing direction definition of the new collection and the assessment of the collection dimension. Triage, when the elaboration (object of inspiration, contemporary form and aesthetics), adequacy (functionality, commercial aspect and cultural aspect) of the product and definition of the themes are analyzed. The Preliminary Project corresponds to the sketches of the models and the choice of colors, shapes, fabrics, trims, components, accessories and labels. Evaluation and Improvement,

Table 1. Fashion Product Development Model proposed by Rech (2002).

\begin{tabular}{|c|c|c|}
\hline Actions taken & Product Development / Fashion & \\
\hline Analysis of previous collections & \multirow{3}{*}{ Concept generation } & \\
\hline Marketing targeting & & \\
\hline Collection dimension & & \\
\hline Elaboration analysis & \multirow{3}{*}{ Screening } & \\
\hline Analysis of suitability & & \\
\hline Fashion information and concept definition & & Project actions \\
\hline Sketches (idea generation) & \multirow{2}{*}{ Preliminary design } & \multirow{2}{*}{$\begin{array}{c}\text { Drawing tools } \\
\text { Drapping }\end{array}$} \\
\hline Composition and material elements & & \\
\hline Technical drawing & \multirow{2}{*}{$\begin{array}{c}\text { Evaluation } \\
\text { Improvement }\end{array}$} & \multirow{5}{*}{$\begin{array}{c}\text { Technical / commercial analysis } \\
\text { (coherence / consumers and the company } \\
\text { expectations) }\end{array}$} \\
\hline Modeling and technical sheet & & \\
\hline Pilot piece & \multirow{3}{*}{$\begin{array}{l}\text { Prototyping } \\
\text { Final design }\end{array}$} & \\
\hline Packing & & \\
\hline Promotional material & & \\
\hline
\end{tabular}


which it develops technical design, modeling and technical data. In conclusion, the Final Project when the pilot piece is developed and approved (or not).

Considering this proposed methodology, it is clear that, when establishing the project actions, the author emphasizes the importance of planning, by collecting and analyzing data, which are fundamental to the quality of the process. In this way, it is able to identify the guidelines for the design and production process, determined by consumer standards and requirements. When investigating the product development methodologies developed by the authors mentioned above, Montemezzo (2003) presented guidelines for the development of fashion products in the academic field. This method (Table 2) is intended for clothing, oriented to the market with programmed obsolescence and that includes, in addition to the function of immaterial values and current aesthetic codes.

Based on the Rech (2002) and Montemezzo (2003) considerations about clothing products development, it is possible to verify the importance of market aspects, users needs and consumers desires in this process. Consumer proximity is considered essential for the product design, due to the high immaterial value attributed to them. Therefore, consumer-focused projects are a fundamental factor in development and, consequently, risk management will be more efficient. The role of immaterial production functions, flexibility and seasonality of production are common characteristics of the clothing sector, even more accentuated in the fast fashion segment. However, Cietta (2010) states that in fast fashion the creative activities developed do not differ from those adopted in the industries of traditional models, but it implies a creative system capable of operating in a double way: innovative, but, at the same time, that incorporates the latest consumption trends.

\section{Case study}

The case study was based on open semi-structured interviews with the owners and technical visits to the company studied in order to assess the following variables: company history, analysis of product development and production process and analysis of the application of fast fashion in the company production process and product development, to meet this work objectives, developed from exploratory research and literature research.

The company has been operating in the clothing industry and commerce market since 1987, being classified

Table 2. Guidelines for the elaboration of fashion products.

\begin{tabular}{|c|c|}
\hline Phases & Actions \\
\hline \multirow{5}{*}{ Planning } & Market perception and opportunities discovery \\
\hline & Reviews / Company expectations and commercial history \\
\hline & Product ideas / Design problem identification \\
\hline & Definition of marketing, development, production, distribution and sales strategies. \\
\hline & Setting the schedule \\
\hline \multirow{4}{*}{ Project specification } & Analysis and definition of the design problem (guidelines) \\
\hline & Summary of the consumer universe (physical and psychological) \\
\hline & Fashion content search (trends) \\
\hline & Project delimitation (objectives) \\
\hline \multirow{2}{*}{ Conceptual Delimitation } & Generation of concepts and definition of the Generator Concept \\
\hline & Definition of functional and style principles \\
\hline \multirow{2}{*}{ Generation of alternatives } & Generation of alternatives to solve the problem (sketches, drawings, model studies). \\
\hline & Configuration settings, materials and technologies \\
\hline \multirow{5}{*}{ Evaluation and Elaboration } & Selection of the best alternative \\
\hline & Configuration details (technical drawing) \\
\hline & Development of technical sheet, modeling and prototype \\
\hline & Ergonomic and usability tests \\
\hline & Corrections and adjustments \\
\hline \multirow{9}{*}{ Realization } & Technical and commercial evaluations \\
\hline & Corrections and adjustments \\
\hline & Graduation of modeling \\
\hline & Making of definitive technical sheet and pilot piece (product technical and commercial approval) \\
\hline & Acquisition of raw materials and trims \\
\hline & Orientation of the production and sales sectors \\
\hline & Definition of packaging and advertising material \\
\hline & Production \\
\hline & Product launch \\
\hline
\end{tabular}

Source: Montemezzo (2003, p. 62). 
as medium-sized, internally composed of 85 employees divided in the production, commercial and administrative areas. Located in Divinópolis, a pole region for the clothing industry in the Minas Gerais central west, called "fashion pole". Its main products are men's shirts in mesh and flat fabric, developed for the market of wholesale multi-brand stores and chains of retail stores, whose target audience is, especially, class $\mathrm{C}$ consumers of the young and adult age group. Products are launched for this consumer market according to the current evidence, which is why the company chose not to develop entire collections by season in advance, adopting product launches according to the predilections signaled by consumers during each season. The sale of these products is $70 \%$ achieved through direct sales and $30 \%$ by sales representatives.

The company develops its own brand and confection for other brands (private label system), serving other niche markets, from companies that buy products and resell them as if they were from their production, with the respective brand label. However, the production of own brands represents $60 \%$ of the total. In the private label system, drawing / photos of the pieces to be made are received from the contracting companies, with the prior choice of fabrics and the various trimmings necessary for the production of the pilot piece and the necessary descriptions, reported in a technical sheet with details of the proposed. However, it is common for the company to suggest to the contractors products developed by it. As the company operates in different regions of Brazil, it is a requirement that it offer products that meet the diverse needs of these consumers, despite a certain homogeneity of the niche in which the company operates. New product ideas arise mainly from trends seen in fashion events, on the streets and in Brazilian soap operas. The trend research carried out by the company is not conceptual, that is, it is not intended to detect rising behaviors, ideas or styles, but focused on products, models, pieces and prints already developed by renowned brands in the men's shirt segment. This stance was defined in an attempt to reduce the risks and the unpredictability inherent in fashion products, thus producing sustained in what is quoted as a sales success and is in evidence in the market.

The company does not have a formal product development department, and the entrepreneurs themselves are responsible for these activities, who do not have training in fashion, but have been in business since 1995 . The company has sometimes employed stylists to develop products for its own brand, but there is no link with the company for cost reasons. Product launches are carried out weekly for both the private label and the others (private label). Despite not having a formal procedure that defines the product development methodology, during the visits and interviews with the entrepreneurs, it was observed and it was possible to determine that in this process the following phases are usually adopted (Figure 1).
When developing the pilot piece (prototype), those responsible for product development seek to remedy all possible costly processes for production, in order to shorten the time of this phase. These design decisions are based on the experiences of both the pilot seamstress (the one whose function is to produce the pilot pieces) and knowledge of the company businesswoman. If any problems occur later, the information is promptly passed on to the developers and alternative solutions are sought. Soon the problems in the production chain are evaluated when the pilot part is made, being corrected and the changes made until the final version is validated.

From the conception of the product to its commercialization (upon request), an average of 30 days is spent (Figure 2). The organization does not have a collection on the evolution of its products and services, however sales information and customer satisfaction level are monitored by the reports of the sales team, due to direct contact with the customer, or by the feedback given by the private label companies.

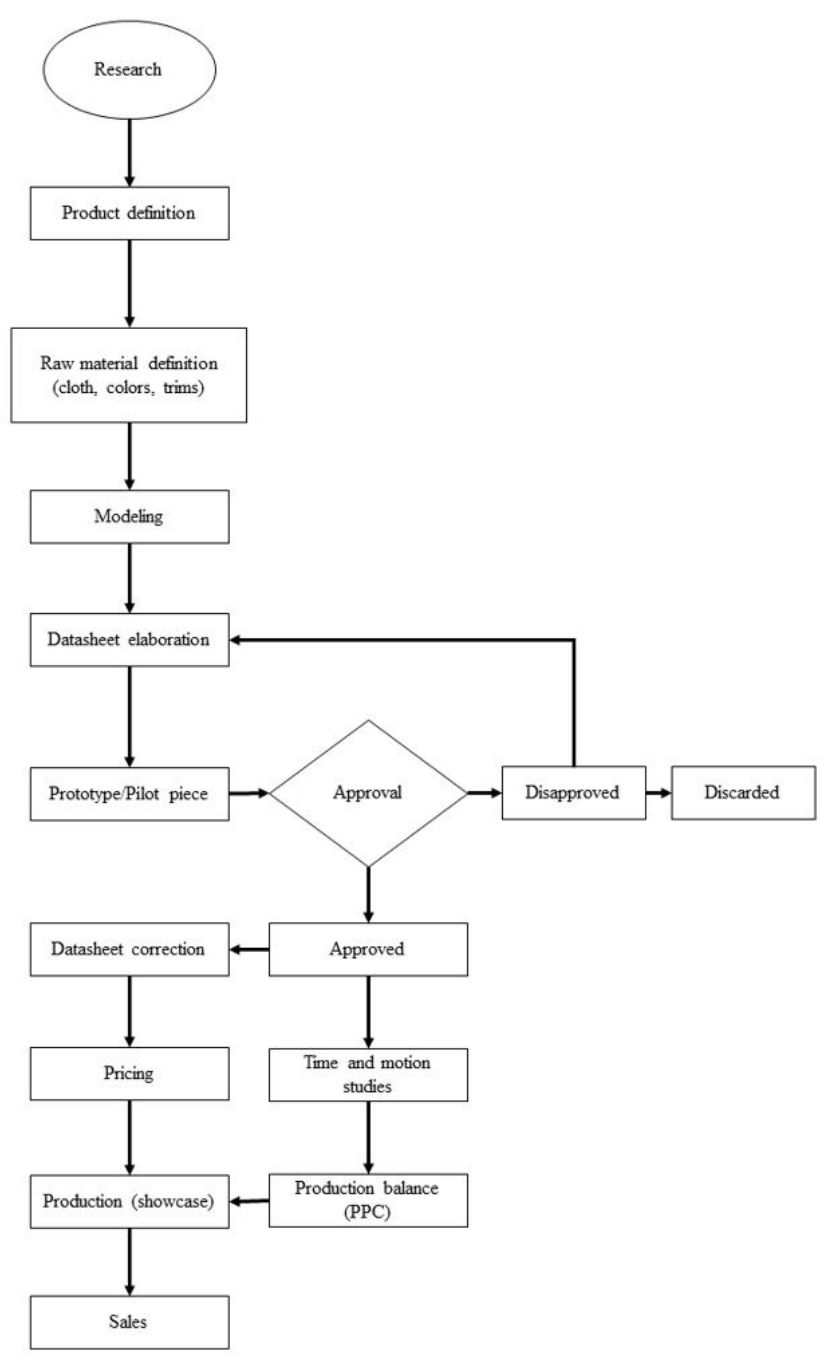

Figure 1. Product development process flowchart. 


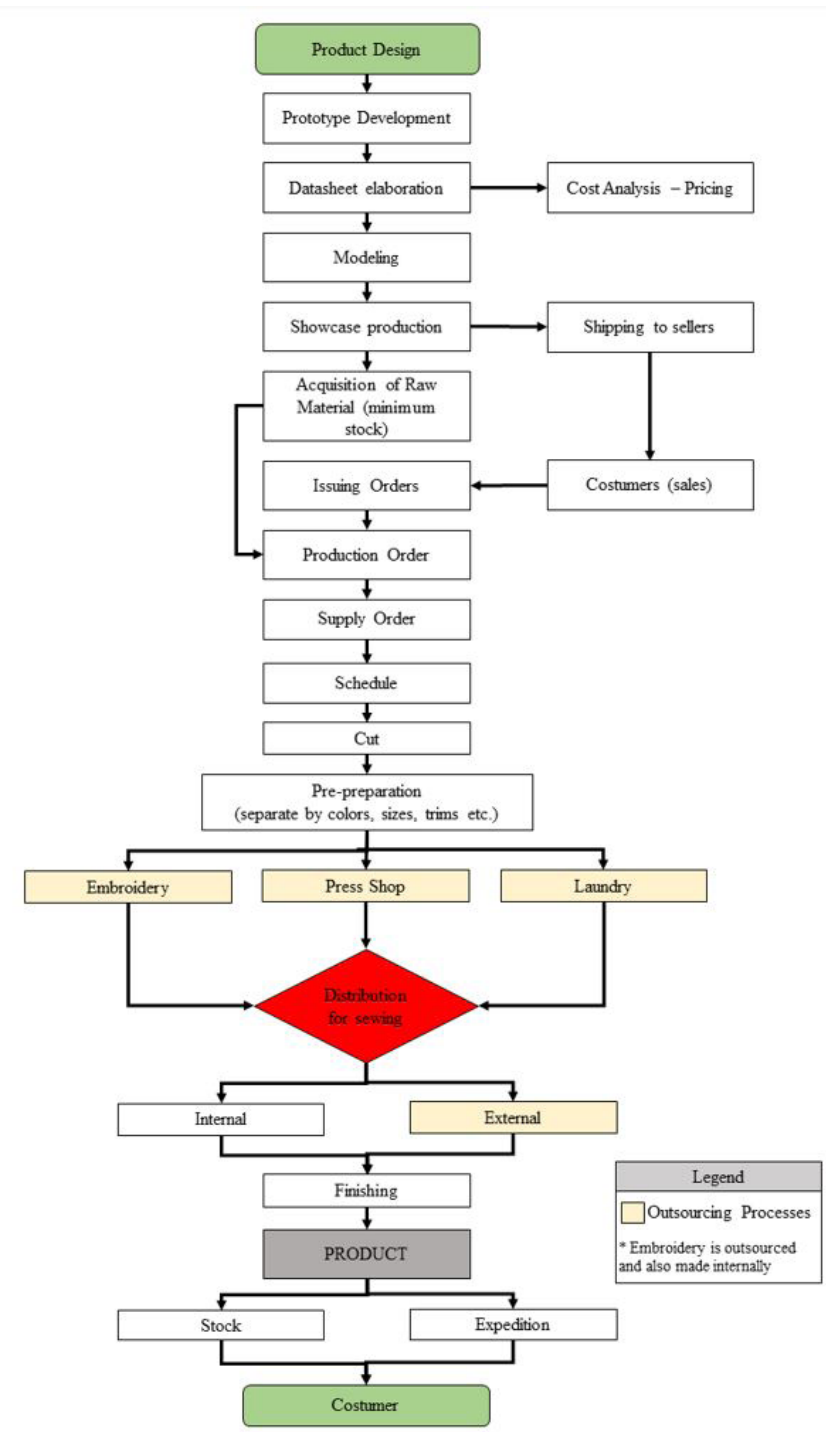

Figure 2. Production chain flowchart.

\section{Analysis and discussion}

Although the product development process models may vary depending on the company and the item, the steps are usually similar. Therefore, the important thing is to understand how the steps are managed. With this objective, the data collected in the case study were analyzed and interpreted considering the theoretical basis of the present work, that is, through the connection between theory and practice. Due to the incentive of promotion agents such as SENAI (Brazilian National Industrial Learning Service) and SINVESD (Divinópolis Clothing Industry Union) for the adoption of the fast fashion model by companies in the region, the company recently promoted some changes for the insertion in this model, being classified as a fast fashion producer, and many of the suggested practices in this new model adopted, they were already observed, how to operate in a highly diversified market and to produce in small (semi-exclusive) lots that allow to permanently renew their models within the same season, since they do not produce collections. In addition, there is also the fact that the search for information about the needs of consumers directly at the point of sale, in this case through salespeople and informal conversations with other retail customers, causing these desires to be translated into their products.

Despite activities shared with those of the fast fashion model, some procedures required changes under what was practiced until then. The main change was in production. In order to reduce the time for the shirt-making process, the cell production system was adopted. Thus, in addition to reducing lead time and consequently gaining in productivity, this new arrangement gave the process a reduction in intermediate stocks and reduced costs, in addition to improving quality control. Under this last aspect, the company is more concerned with quality control. The most elaborate products are made internally and the rest of production is outsourced, contrary to the criticisms made of fast fashion products. Another change inherent to the adoption of this production system was in relation to the measurement of the time of each stage of production, which starts to be timed during the making of the pilot piece and no longer an average of these operations during the actual production, because in fashion product may not be produced in more than one batch. The fact of producing new models weekly clarifies this situation (flexibility).

However, it is in the creative process that traces of the model previously employed by the company, ready fashion, can still be seen. The company's products are still mostly based on best sellers or inspired by established brands in the market. However, it was also noticed during the interviews that there is a tendency that is based on feedbacks from sellers in addition to inspirations in characters from soap operas. It can be concluded that the company, despite being classified as a fast fashion producer, still brings in its processes and strategies characteristic of ready fashion, that is, it is still in transition between the two models.

Regarding the characteristics of the product, as stated by Cietta (2010), despite the regional diversities of its consumers mentioned by the entrepreneurs, it is the communication between the company and consumers mediated by salespeople which enables it to offer products oriented to the local market, in addition to their experience in the business, unlike stylists / designers who have worked in the company. Although part of the manufacturing is for other brands, the industry is capable of serving markets ranging from class $\mathrm{C}$ to class $\mathrm{A}$. These seem to be characteristics of small and medium-sized Brazilian fast fashion industries, which seek competitiveness through creativity, although they do it in an unprofessional way, without the guidance of stylists. The adoption of a more structured method can 
strengthen the company's product development system and consequently increase the chance of success of its products, in addition to acting in strengthening its own brand, which is essential for fashion companies. You cannot create a solid brand in the market by acting as an outsourcer to other companies, in the private label model.

\section{Final considerations}

The textile industry is an important productive segment for Brazil. However, it is a poorly studied sector and needs procedures and tools to improve its efficiency, in the face of competition from imports. The launch of differentiated products has quickly been seen as a way out of the growing competitive pressure. A fact that makes the fashion industry very complex due to the rapid obsolescence of its products and that consequently poses a challenge in designing them.

The most significant change that is taking place in the fashion production chain is the fact that production starts to be dictated by end customers, who seek to determine product and production criteria. This new formatting of the chain is related to the progressive incorporation of the immaterial. The modernization of the industry by material means (investments in machinery and raw materials) remains important, but more and more is not enough $(\mathrm{RECH}, 2002)$. The introduction of the fast fashion model in the Brazilian market has caused structural changes in the fashion industries so that they adapt to this new format, as demonstrated in this article. What can be seen from this study is that, differently from what the critics claim about the great drivers of this model, smaller national companies are adapting fast fashion in a way that can have a fast change in their products, guaranteeing the product quality and adequate working conditions. This model has opened up new possibilities for companies to bet on flexibility and speed of responses as a major competitive advantage.

Fast fashion has become a differentiation model mainly for small and medium-sized national companies, with that the application of a specific product development method for these institutions tends to better guide and direct the performance of these companies. According to Kotler (2011), structuring the product development process entails investment in technology and organization of processes, reducing time, costs and steps. The perspective for fast fashion companies is one of growth, so they need to remain in a constant process of change and adaptation to favor their strategies. However, the lack of case analysis turns out to be an obstacle for Brazilian companies that do not know how this model is achieving success in the country, which model is adopted by national companies and how they organize themselves, in addition to ignoring the competitive advantages already produced.

\section{Acknowledgements}

The authors would like to thank FAPEMIG - Minas Gerais State Research Support Foundation (FAPEMIG) for the financial support to the TEC project - APQ-01843-15: "Analysis of the Life Cycle of Products in Minas Gerais". The authors also thanks to Professor Matheus Luiz Pontelo Souza by his gentle collaboration presenting this research at the $20^{\text {th }} \mathrm{CBGDP}$ and Isadora Paloma Linhares Ribeiro, by her collaboration in the flowchart figures.

\section{References}

CIETTA, E. A revolução do fast fashion: estratégias e modelos organizativos para competir nas indústrias híbridas. 2. ed. São Paulo: Estação das Letras e Cores, 2010.

DELGADO, D. Fast fashion: estratégia para conquista do mercado globalizado. ModaPalavra e-periodico, v. 1, n. 2, 2008, p. 2-10. Available from: <http://www.ceart.udesc.br/ modapalavra/edicao2/files/fast_fashion-daniela_delgado. pdf $>$. Access in: 20 May 2018.

GIL, A. C. Métodos e técnicas de pesquisa social. 7. ed. São Paulo: Atlas, 2019.

KOTLER, P. Administração de marketing: análise, planejamento, implementação e controle. 5. ed. São Paulo: Editora Atlas, 2011. 726 p.

MONTEMEZZO, M. C. F. Diretrizes metodologias para o projeto de produtos de moda no âmbito acadêmico. 2003. 97 f. Dissertação (Mestrado em Desenho Industrial)Faculdade de Arquitetura, Universidade Estadual Paulista, Bauru, 2003.

MUNARI, B. Diseño e cominicación visual: contribución a una metodología didáctica. Barcelona: Editorial Gustavo Gilli. 1975.

OLIVEIRA, G. Construindo um sistema de desenvolvimento de produtos em empresa têxtil por intermédio de gestão de portfólio e de QFD. 2007. 188 f. Dissertação (Mestrado em Engenhara de Produção)-Departamento de Engenharia de Produção, Universidade Federal de Minas Gerais, Belo Horizonte, 2007.

PESSÔA, M. V.P.; TRABASSO, L. G. The product development system. In: Pessôa, M. V. P.; Trabasso, L. G. (Ed.). The lean product design and development journey. New York: Springer, 2017.

RECH, S. Moda: por um fio de qualidade. Florianópolis: UDESC, 2002.

SANTIAGO, C.; MORELLI, G. Inovação no varejo: fast fashion e pop-up stores. In: CONGRESSO DE INOVAÇÃO, TECNOLOGIA E SUSTENTABILIDADE, 1., 2010, Brusque. Anais... Brusque: UNIFEBE, 2010. 11 p. Available from: <http://sites.unifebe.edu.br/congressoits2010/artigos/ artigos/062_-_INOVACAO_NO_VAREJO_FAST FASHION_E_POP_UP_STORES.pd $\overline{\mathrm{f}}>$. Access in: 13 Oct 2017.

SLACK, N. et al. Administração da produção. São Paulo: Atlas, 2018. 